\title{
Strategic news frames and public policy debates: Press and television news coverage of the euro in the UK
}

\begin{abstract}
There is growing concern amongst observers of the media that news coverage of politics has moved away from a focus on issues, and instead towards political strategy. Research evidencing such concerns has tended to examine strategic news at a macro level and rarely delves into the complexities surrounding its manifestations. This study addresses this issue by conducting a content analysis of a non-election issue in the British news media (press and TV news) over a three-month period, whereby examining strategy news as a frame. The issue chosen for case study was the "euro debate" of May-June 2003. Findings showed the euro debate to fulfil many typical characteristics of EU reporting in the British media, with coverage cyclical and driven by events, and subsequently lacking sustained engagement with the issues. Although there was a roughly equal balance of issue and strategy framed stories in the press, certain features of coverage gave strategy greater prominence. Despite much of the content analysis's findings confirming the worries of media critics, a number of qualifications emerge, such as the active role that politicians play as sources of strategic news.
\end{abstract}

Keywords: Britain, content analysis, EU coverage, media framing, strategic news.

\section{Introduction}

Amid the burgeoning research on the news media's role in democratic life, a growing number of studies have established journalists' increasing tendency to focus on the game of politics at the expense of substantive issues. Largely referred to as strategic news, this type of reporting draws attention to the motivations of politicians' actions in the public sphere, and discloses the strategies and tactics employed in battles for political gain. In the strategy structure, a politician's policy positions are interpre- 
ted as a means of attracting a certain segment of voters, or of outflanking a political opponent, rather than as a genuine (even if flawed) attempt to solve the problems of society (Cappella and Jamieson, 1997, p. 34).

Yet despite a proliferation of research examining the presence and effects of strategic news, very few have been conducted in the UK, and most studies opt for sample breadth at the expense of in-depth analysis of the features of strategic news. This leaves a number of unresolved questions regarding strategic news, which are discussed in the following literature review. Drawing upon the findings of a UK press and television news content analysis of the 2003 "euro debate", this study aims to fill some of these gaps in knowledge.

\section{Political strategy in the news: An overview}

Amongst content analyses conducted since the early 1990s, the predominance of strategic frames in the narrative of election coverage has been well established (e.g. Esser and D'Angelo 2003; 2006; Jamieson 1992; Just et al. 1999; Patterson 1993), with typically between $50-80 \%$ of election stories focussing primarily on political strategy. Even outside election periods, strategic frames have been found to permeate political coverage, (de Vreese et al. 2001; Lawrence 2000; Morris and Clawson 2005; Skorkjaer Binderkrantz and Green-Pedersen 2009), though usually to a lesser extent than during elections.

By choosing to frame politics in strategic terms, laying bare the ruthless and power-hungry nature of the political system, the news media have been accused of stirring-up a "spiral of cynicism" amongst the electorate, whereby political cynicism, leading eventually to disengagement from politics, is cultivated. A number of empirical investigations have given weight to this claim, finding causal connections between strategic news exposure and political cynicism (e. g. Cappella and Jamieson, 1997; de Vreese, 2004; de Vreese and Elenbaas, 2008; Valentino et al., 2001), though the long-term effects of this news are less clear.

It is notable that much (though not all) of the research concerning strategic news is as a news frame. This is probably because the framing paradigm offers a compelling account of journalistic power: the ability of journalists to draw attention and confer legitimacy to one aspect of reality (in our case the motivations and campaigning tactics of politicians) while marginalising other aspects (such as the policy positions of politicians, how these might be resolved, and the potential impact of public policy). Entman (2005, p. viii) claims that framing is inescapable, and is at work every time someone crafts a message. Journalists therefore cannot choose not to frame their stories, even though the degree of con- 
sciousness and intention varies (Stromback and Dimitrova, 2006). Framing also offers a theory of frame building and frame setting which can help understand both the content and effects of news media. Over time strategic news has become thought of as a generic news frame. This means that in a number of different contexts and strategic frames have been found to represent a journalistic norm in presenting the day's events (see de Vreese, 2005a).

\section{Where next for strategic news scholarship?}

The literature discussed so far offers considerable value in demonstrating the rise of strategy frames as a means by which journalists present politics. But this research is not without its shortcomings, and so a number of outstanding questions still remain. These are listed below, and form the hypotheses and research questions underpinning this study.

Questions remain as to the features of strategy frames most commonly used. As important as the extent of strategy frames adopted by journalists is how they are manifest. If we accept strategy as an overarching metaframe, then it has a number of sub-elements. Cappella and Jamieson (1997, p. 33) conceptualise it as follows:

(1) winning and losing as the central concern; (2) the language of wars, games, and competition; (3) a story with performers, critics, and audience (voters); (4) centrality of performance, style, and perception of the candidate; (5) heavy weighting of polls and the candidate's standing in them.

These are the benchmarks from which strategic news has been conceptualised and operationalised in this field; though it is notable they have not always translated directly into coding categories. It is important for research to explore which elements of the strategic metaframe are most prevalent, and under which circumstances they are most likely to appear (de Vreese, 2005b). This becomes especially pertinent when we consider the suggestion made by experimental studies that some aspects of the strategic metaframe are more likely to cause political cynicism than others (Valentino et al., 2001). However, it has been quite common for studies (often large-scale and cross-national) to examine the strategy frame as a single entity, thus overlooking the sub-stories. Some recent research has given more attention to strategic subframes (Stromback and Shehata, 2007), finding nearly $50 \%$ of press articles about the 2005 UK General Election focussed on the motivations of politicians (what they call the "political strategy" subframe), and $31 \%$ included an element of the horse race. 


\section{Dan Jackson}

Compared to non-election periods, election campaigns offer more opportunities to report on winning and losing, supported by daily opinion polls. Elections are also punctuated by highly orchestrated media opportunities, as the candidates travel the country speaking to the public. Such events give the news media reason to offer a strategic slant on the style and performance of politicians, and their use of public relations. As the present study is set against the backdrop of a non-election public policy debate, we might expect less strategic news and more issue-based news in general, and less use of the horse race and presentation style as strategic subframes. On the other hand, policy debates can be bitterly contested, dividing political parties and the public. This sort of conflict is often associated with strategic frames (de Vreese, 2005a) as it can provide journalists with opportunities to analyse the disagreements (personal and policy) and subsequent party prospects in strategic terms. As a baseline of understanding how strategy frames work in the UK outside of elections is still yet to be established, the first research question asks:

RQ1: Which subframes of the strategic metaframe are most commonly used?

Research is unclear on whether strategy frames are more prevalent in the press or on TV news. Many scholars have claimed that the visual nature of television and the practices of news organisations predispose it to a different product from newspapers. In particular, TV news content supposedly emphasises individual attributes such as the personalities of candidates, at the expense of issue coverage (Iyengar, 1991; Semetko and Valkenburg, 2000). Still, when it comes to the strategy frame the evidence for these differences between mediums is not that clear. In the USA, the Project for Excellence in Journalism (PEJ) (2004) and Druckman (2005) found little substantive differences between mediums. However, Just et al. (1999) found that newspapers still provided more substantive coverage of presidential campaigns than TV. As there is scant evidence regarding this point from the UK, where broadcast and press journalists have more distinct cultures compared to other countries, I have chosen to ask the following research question instead of posing a hypothesis:

RQ2: Is strategy news more prevalent in television news or in the press?

Relatively little research has examined the differences between media sectors and strategy frames. Patterson $(1993 ; 2000)$ argues that commercialism is the driving force behind the strategic framing of politics. If this is true, then we would expect to see less strategic news in public funded television news broadcasts than in commercial ones. However, the evi- 
dence to date has not always supported this. When PBS channels were compared to commercial ones in the US, Kerbel et al. (2000) found little substantive difference between the two in their use of strategy frames. In a comparative study of election news in Sweden and Belgium, however, Stromback and van Aelst (2009) found commercial TV channels focussed on the game of politics substantially more than their public service counterparts. In Britain, all terrestrial television channels have a PSB tradition, meaning the forces of commercialism have traditionally been kept in check, and there is a less clear difference between the agendas of different broadcast news outlets (see Barnett et al., 2000). For this reason, we would not expect the sorts of differences seen elsewhere:

H1: The amount of strategically framed news will not significantly differ between commercial and public funded broadcasters.

Previous research has largely overlooked strategy frames in different sectors of the press. Although both tabloid and quality newspapers are commercially funded, on the whole, quality newspapers are more reliant on advertising income and subscriptions for their income, whereas tabloids rely more on daily newsstand sales, meaning they compete for readers on an everyday basis (Allan, 2004; Stromback and van Aelst, 2009). Tabloids, therefore, feel greater financial imperatives to present news in a format that has significant entertainment and interest value, even at the expense of civic or educational value (Hahn et al. 2002; Kuhn 2003). Strategic frames should therefore appeal more to tabloid journalists, as the uncertainty and suspense associated with the depiction of politicians as strategic players, plus the focus on personality-related stories, is more likely to catch and hold the audience's attention than the substantive aspects of the election or issue debate.

H2: Strategically framed news will be more common in tabloids than in quality newspapers.

Little research has considered the role of politicians in the construction of strategy frames. Underlying much literature critical of media coverage of politics is an assumption that political strategy is the fixation of journalists, and that politicians are more interested in issues. Recent evidence from the UK throws this into doubt, however. In his analysis of press releases in the 2005 election, Gaber (2006) reported that the parties had made election strategy and tactics their single biggest issue, with Labour and the Conservatives devoting around $47 \%$ of their announcements to either attacking their opponents, or urging voters to get out and vote (or not vote for their opponents). This suggests that strategy stories are 


\section{Dan Jackson}

not just the invention of journalists, but can actually be driven by the agendas of the parties themselves. Britain has an adversarial political culture, producing regular bouts of political conflict that make their way into the news (see de Vreese, 2005a). Therefore, despite the silence of framing research on who is driving strategic news, we should expect politicians to be active sources, not just passive victims of strategic news:

H3: Politicians will be active in the strategic framing of politics.

\section{The 2003 Euro debate}

Given that the focus of most scholarship concerning strategic framing has been in the context of elections, there is a strong case for examining it in a non-election context. The policy debate chosen for this study is that of British membership of the European single currency. More specifically, the content analysis focuses on the "euro debate" of May/ June 2003, leading up to Gordon Brown's announcement of the "five tests" for euro entry. The then Chancellor of the Exchequer gave his announcement of the five tests on the $9^{\text {th }}$ June 2003, when he advised against Britain joining the single currency but left the door open to a potential referendum before the next election. In terms of examining the strategy frame, this case study appeals because it arguably offers the shared narrative of a saga (see Lawrence, 2000), which is the culmination of a policy debate ( $9^{\text {th }}$ June). According to Lawrence (2000), the journalists' use of strategy and issue frames during policy debates can ebb and flow depending on circumstances. For example, she found a peak in strategy coverage as the "finishing line" of the legislative decision date approached, because speculation over the political winners and losers intensified, and the metaphor of the race became more potent. As the euro debate of 2003 had a decision date, we would expect to see similar patterns in a British policy context:

H4: Strategy news will be more prominent towards the culmination of the policy debate ( $9^{\text {th }}$ June 2003).

Selecting a single case study helps achieve the aim of examining the characteristics of strategic news in some depth, but means that longitudinal breadth is lost. This is a limitation. Whether the single currency represents a "routine" policy issue or not is also an important consideration. Over the years, the relationship between the Britain and the EU has possibly evoked more passion, division and bitterness amongst the British public, politicians and media than any other issue. There have also been clear proprietor agendas in the press that in the past have seen 
reason and impartial reporting evaporate. Content analyses have found coverage of EU affairs in the British media to be amongst the most negative (anti-EU) and conflict-based in the whole of the EU (de Vreese et al., 2006; Gleissner and de Vreese, 2006; Pfetsch, 2004). At the same time, the news media holds a particularly influential role in public knowledge and opinion about European affairs. This is because the British public are more like "observers" rather than "participants"; they do not have multiple sources of information on which to base their opinions, such as personal experience of public services, the health of the economy and so on (Gavin, 2000).

Because of the division and conflict both within and between British political parties regarding the EU, and with the press often adopting a campaigning stance (Firmstone, 2008), we might therefore consider it a special case when analysing journalistic trends. In some ways this may be true, but the consequences of this for the strategy frame are not clearcut. For example, an abundance of elite conflict can be double edged: on the one hand, it prompts news organisations to give more attention to the issue, which can force them to explain the substance of the issue to their audiences; on the other hand, it also licenses journalists to treat the conflict as a game, emphasising the strategic angles of the conflict as much as the substantive. Furthermore, it can be easy to overplay the distinctiveness of EU politics in the news. For example, the elite conflict associated with Europe (or at least its portrayal), although considerable, is not unique, and issues such as immigration, taxation and war have divided British parties and stirred the press in similar ways.

\section{Sample and method}

The sample period consists of 34 days ( $11^{\text {th }}$ May to $15^{\text {th }}$ June 2003), in which coverage of the euro was most intense. Only articles where British membership of the euro was the main focus were included ${ }^{1} .786$ articles were coded from 18 national daily and Sunday newspapers representing all segments of the market, as well as the left and right of the political spectrum. These titles constitute the vast majority of daily and Sunday national newspaper purchases in the UK. All sections of the newspapers were analysed, except for pull-outs. Television news broadcasts chosen for analysis were the $B B C 10$ o'clock News, ITN News at Ten, Channel 4 News (at $7 \mathrm{pm}$ ) and Five News (at $7 \mathrm{pm}$ ), which yielded 39 news items (constituting 198.28 minutes of coverage) that were related to the euro debate in Britain.

Previous framing research shows many variations in the way that frames are operationalised (see D'Angelo and Kuipers, 2010). For many of these studies, frames are measured for their presence through dichoto- 


\section{Dan Jackson}

mous indicators, coded on a presence-absence basis (e.g. de Vreese, 2005a; Semetko and Valkenburg, 2000; Stromback and Shehata, 2007). Typically, between two and four framing measures are used for each indicator ${ }^{2}$, meaning that a score of 0.5 could be coded for a story that has part of a frame present, but not all of it. This system provides the inspiration for the present study, but was adapted in recognition of its potential flaws. For example, a news story might be wholly focused on political strategy, but the focus is on only one or two elements of it, and so the score for the presence of the strategy frame might be 0.5 . This system would be potentially misleading because from the audience's point of view it does not matter whether two other indicators are not present, if the story is wholly focused on strategy then that is what an audience sees. With this in mind, the present study aimed to develop a system of measuring frames that most accurately reflects the impression of a story that the audience would receive. For the sake of easy comparison with other studies, a presence-absence $(1-0)$ scale was still used for subframes, but in addition to this their absolute frequency was recorded.

All articles were coded into two meta frames: strategy and issue. The unit of analysis is the news story. Articles were analysed and every sentence that applied to one of the frames was added to a tally. At the end of each article, the tallies were added up and the total frame for each article was placed into a 5-point scale, from "very strategy" to "very issue", with the mid-point being a "mixed" frame, depending on the proportions of $\mathrm{each}^{3}$. The advantage of calculating an overall balance between the frames is that it enables us to address the inevitable variations in story length that occurs, both within and between newspapers and broadcasters.

In order to achieve a more textured insight into the way the euro debate was covered (RQ1), within the strategic metaframe, there were three subframes, which were informed by Cappella and Jamieson's (1997) conceptualisation. The most consistently cited element of strategy reporting is the journalistic interpretation of a politician's motivation for taking a particular policy stand: This will be referred to as the political strategy frame (see Stromback and van Aelst, 2009). Stories containing this element directly imply that politicians are interested primarily in outflanking their rivals and garnering votes, not sincerely pursuing solutions for important social problems (Cappella and Jamieson, 1997). As suggested earlier, there is considerable value in examining whose political strategies were being highlighted and under what circumstances. With this in mind, the political strategy frame was therefore examined at four levels, based on observations made at the pilot stage: "Brown/Blair relationship" accounts for references to the relationship between Prime Minister and Chancellor as a strategic game or struggle for power; "Intra- 
cabinet politics", "Intra-party politics" and "Inter-party/camp/lobby politics" include portrayals of politicians as adopting policy positions in order to outflank their cabinet, party or opposition party colleagues. With the exception of the "Brown/Blair relationship", the categories were designed to be applicable outside of the present case study.

The component of horse race frame represents a typical element of strategic reporting (e.g. Farnsworth and Lichter 2007; Patterson, 1993), and is the second subframe. Although the euro debate was not an election campaign, public opinion towards European integration (including the euro) is regularly polled and so would be available for journalists to use as a news hook for offering attributions about the reasons for political success or failure. The horse race frame was defined as stories focused on winning and losing in the battle for public opinion. It included references to polls, but also references to public opinion outside of polls when in the context of winning or losing public support. As Cappella and Jamieson's (1997) earlier definition suggests, another important part of the strategy meta frame is the emphasis on presentation style and performance (Cappella and Jamieson, 1997). The third subframe - presentation style frame - included the journalist focusing on the style and aesthetics of a speech or statement, rather than its content. This subframe also included reporting on the use of public relations and communication strategies by politicians in order to look good. As all conceivable aspects of the strategic meta frame are unlikely to be covered by the subframes I have developed (see Stromback and van Aelst, 2009), a category of other was applied ${ }^{4}$.

Coding was completed by the author. A graduate student coded a randomly selected subset of news items. This subset constituted $15 \%$ of the total sample (109 press articles and 15 television news stories) and included articles from all 18 newspapers and 4 TV news broadcasts. The graduate student was fully trained and supervised frequently. Questions were resolved during regular meetings during the coding. We reached an average inter-coder reliability of .88 across all categories (including chance agreement), using Cohen's Kappa ${ }^{5}$. The level of agreement was considered robust. Detailed information regarding the coding instrument, procedures, and instructions can be obtained from the author on request.

\section{Findings}

Figure 1 gives an overall picture of how the frames for each newspaper article and TV report were distributed. It shows that the spread of frames in newspapers is fairly even, with almost as many issue as strategy frames. Even though around $60 \%$ of press stories were clearly framed 


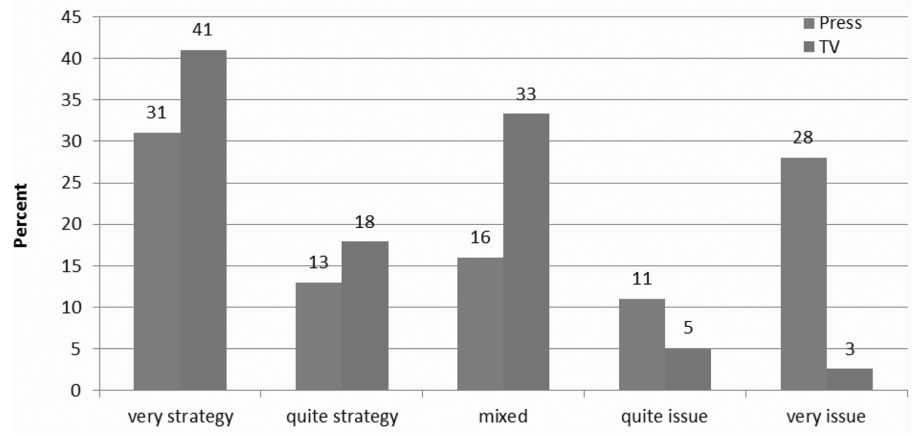

Figure 1. Overall frames in the press and TV news.

in the direction of "very strategy" or "very issue", there were very few that had no references to both frames. $86 \%$ of newspaper articles had at least one reference to a strategy subframe, and $85 \%$ had at least one issue frame reference. This shows that even the stories that focused most on the issues were still likely to draw upon the strategy frame at some point.

There are clear differences between the press and TV news in their framing of the euro debate (RQ2), and an overall frame mean of 2.10 (out of 5 , with $1=$ very strategy and $5=$ very issue) for TV news compared to 2.93 for press confirms this. TV news was far more likely than the press to frame the euro debate in strategy terms, with less than $10 \%$ of stories containing more issue references than strategy, and over $40 \%$ framed "very strategy". As with newspapers, very few stories were exclusively one frame $(97 \%$ had at least one mention of a strategy subframe, and this was $90 \%$ for the issue frame).

The element of time helps understand the pattern of coverage, and whether strategy news is more prominent towards the culmination of a policy debate (H4). Figure 2 compares the total number of press articles on the single currency across all newspapers, with the direction in which they were framed. TV news is excluded because coverage was too inconsistent, though the peaks in coverage and trends in news frames largely mirrored those of the press.

Looking firstly at the amount of news on the euro, for both newspapers and TV news, there are roughly two waves of coverage: the first appearing through mid-May and the second around the decision announcement of $9^{\text {th }}$ June. Before, after, and between these two periods, the single currency struggled to get into the news. From what we know of EU news in various countries, this cyclical coverage is quite typical (Gleissner and de Vreese, 2005). 


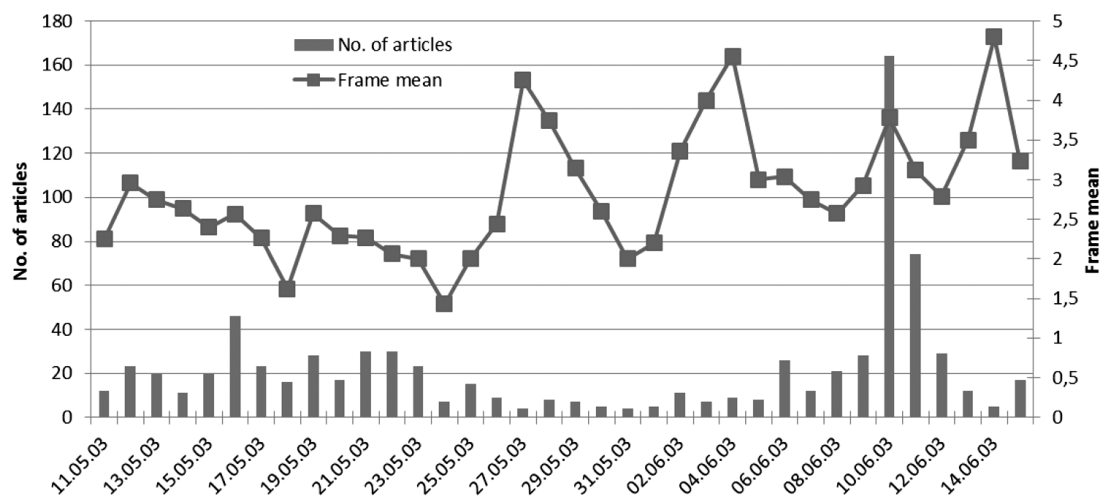

Figure 2. The visibility and direction of the euro debate in the press over time. Note: On the right-hand $\mathrm{Y}$ axis, $1=$ very strategy, $3=\operatorname{mixed}$ and $5=$ very issue.

What was driving news on the euro? Figure 2 suggests that most of the coverage of the single currency during May 2003 was driven by strategy news, such as the government's tactics in presenting their euro decision and the perceived divisions within the cabinet about the issue. There was a stream of stories about party infighting in May that generated many strategic stories. These included Tony Blair's announcement that the whole Cabinet would decide whether to hold a referendum on the euro (May $15^{\text {th }}$ ), which was interpreted as an attack on his Chancellor, Gordon Brown. Then there was the news (on May $15^{\text {th }}$ ) that the euro announcement would be delayed from $7^{\text {th }}$ June until $9^{\text {th }}$ June. Peter Mandelson then announced (May $20^{\text {th }}$ ) in a leaked "off the record" discussion with journalists that Blair has been "outmanoeuvred" by a "politically obsessed" Brown over the euro, thus intensifying speculation about their relationship. As these stories died down in late May and early June when there was very little news on the single currency. In the press, this period coincides with some big peaks in issue frames, although these took place within a much-reduced quantity of coverage. During this period of relative calm, the press and TV largely lost interest in the story. These findings confirm the view that the EU itself is not seen as inherently newsworthy; rather it becomes newsworthy when associated with political conflict (Gleissner and de Vreese, 2005).

During the peak of interest in the EMU story (June $9^{\text {th }}$ ), coverage was more likely to be based on issues, but far from convincingly so. Of all (313) "quite issue" or "very issue" framed press articles, $43 \%$ were on the two days after the $9^{\text {th }}$ June announcement. Given that this almost matches the total number of issue-based articles across the rest of the 32 day sample, it demonstrates that substantive engagement with the issue 
Table 1. Overall frame means in the press by type of newspaper

\begin{tabular}{lllr}
\hline Newspaper & $\begin{array}{l}\text { Average tone } \\
\text { towards the euro }\end{array}$ & $\begin{array}{l}\text { Overall } \\
\text { frame mean }\end{array}$ & $\begin{array}{l}\text { Total number } \\
\text { of articles }\end{array}$ \\
\hline Daily Telegraph & -0.19 & 2.78 & 73 \\
The Times & -0.10 & 2.93 & 131 \\
Independent & +0.27 & 3.30 & 77 \\
Guardian & +0.18 & 3.13 & 101 \\
Financial Times & +0.13 & 3.20 & 84 \\
All broadsheets & +0.05 & 2.99 & 527 \\
Daily Mail & -0.36 & 2.97 & 69 \\
Daily Express & -0.02 & 2.92 & 52 \\
All mid-markets & -0.21 & 2.92 & 130 \\
Daily Mirror & +0.36 & 3.21 & 67 \\
The Sun & -0.57 & 2.29 & 49 \\
All tabloids & -0.03 & 2.68 & 129 \\
\hline Total & -0.02 & 2.93 & 786 \\
\hline Notes: Sunday newspaper & &
\end{tabular}

Notes: Sunday newspapers are not displayed in this table but were used in the calculations of sectors. The overall frame mean was calculated on a 5 point scale, with very strategy $=1$ and very issue $=5$. The average tone for each newspaper was calculated by subtracting the number of anti-euro articles for each paper from the number of pro-euro articles and dividing this sum by the total number of articles for each paper. For all newspapers the average tone therefore ranges from +1 to -1 , regardless of the number of articles.

was largely concentrated around this key date, and not in the lead-up to it. In contrast, only $18.7 \%$ of the total (346) "very strategy" or "quite strategy" framed articles were immediately after the decision, suggesting this frame was more consistently spread throughout the sample period. $\mathrm{H} 4$ therefore received only mixed support.

$\mathrm{H} 2$ was concerned with the differences between types of newspapers in their proportions of strategy news. Table 1 shows that tabloids were marginally more slanted towards strategy reporting than broadsheets and mid-markets, appearing to offer some support for $\mathrm{H} 2$, but it is worth looking at individual newspapers as well. Within the tabloids, for instance, the pro-euro Mirror had far less strategy news than the antieuro Sun, whose reporting was by far the most strategy framed of all newspapers. With the exception of the Express, there appears to be a trend whereby pro-euro newspapers tended to focus more on the issues than anti-euro ones, independent of sector. This could be coincidence or it could reflect editorial policy: by framing EMU around strategy, the suggestion is that the motives of political actors involved (especially in government) are perhaps cynical and self-serving. This discredits the government's pro-EMU case. For the pro-euro newspapers, there is perhaps recognition that in order to persuade readers of the benefits of 
Table 2. How different television sources framed the single currency

\begin{tabular}{llcc}
\hline Source & $\begin{array}{l}\text { Overall source } \\
\text { frame mean }\end{array}$ & $\begin{array}{l}\text { Total number } \\
\text { of appearances }\end{array}$ & $\begin{array}{c}\text { \% of total } \\
\text { air time }\end{array}$ \\
\hline Newsreader & 2.18 & 38 & 9.2 \\
Correspondent & 3.03 & 34 & 34.9 \\
Political editor & 1.29 & 21 & 25.9 \\
Guest pundit & 1.75 & 4 & 7.1 \\
Government politician & 4.05 & 21 & 13.4 \\
Opposition politician & 1.71 & 7 & 3.0 \\
Private sector source & 4.67 & 3 & 3.7 \\
Member of public & 5.00 & 2 & 0.8 \\
Other & 3.00 & 2 & 2.0 \\
\hline Total & 2.63 & 132 & 100.0 \\
\hline
\end{tabular}

Notes: The overall author frame mean was calculated on a 5 point scale, with very strategy $=1$ and very issue $=5$. The percentage of total air time represents the proportion of total coverage (198.39 mins) that each source was given.

EMU, they need to be educated on the issue. These newspapers were also probably more open to the government's framing of the euro question, which stressed that the decision rests on the merits of the economic case for adopting the euro. Given the balance of evidence, $\mathrm{H} 2$ must be rejected.

There were few substantive differences between publicly funded and commercial broadcasters in terms of how they framed the EMU issue, with the overall frame means barely deviating from the collective mean of 2.10 reported earlier. Although the BBC devoted the largest number of stories to the euro debate, its substantive coverage does not appear to have been elevated towards a focus on issues. H1 is thereby supported.

Table 2 illustrates how different sources in television news affected content. Correspondents and political editors both in terms of their number and length of appearances dominated coverage. Interestingly, government politicians appeared as many times as political editors, but they were given half as much air time ${ }^{6}$. Opposition politicians received even less visibility in the framing of the issue.

There are some stark differences in the direction of each source's contribution to the euro debate, which help uncover how the story was framed overall. Correspondents might give a balanced account of the day's events, including some background to the issue. Political editors such as Nick Robinson (ITV) and Andrew Marr (BBC) offered the most strategy-based interpretation of the EMU issue, assessing what the day's news meant for party prospects and the ambitions of the individuals involved. When sources were used, we can see that government politicians (usually Gordon Brown) were keen to focus on the policy issues at 
Table 3. Breakdown of strategy subframes (in \%)

\begin{tabular}{llllllll}
\hline & $\begin{array}{l}\text { Brown/ } \\
\text { Blair } \\
\text { relation- } \\
\text { ship }\end{array}$ & $\begin{array}{l}\text { Intra- } \\
\text { cabinet } \\
\text { politics }\end{array}$ & $\begin{array}{l}\text { Intra- } \\
\text { party } \\
\text { politics }\end{array}$ & $\begin{array}{l}\text { Inter party/ } \\
\text { camp/ } \\
\text { lobby } \\
\text { politics }\end{array}$ & $\begin{array}{l}\text { Horse } \\
\text { race }\end{array}$ & $\begin{array}{l}\text { Presen- } \\
\text { tation } \\
\text { style }\end{array}$ & Other \\
\hline $\begin{array}{l}\text { Press stories }(\mathrm{N}=786) \\
\text { Mean } \\
\text { references }\end{array}$ & $2.18(1.87)$ & $0.66(0.56)$ & $0.4(0.34)$ & $0.6(0.52)$ & $0.57(0.52)$ & $1.5(1.33)$ & $0.8(0.07)$ \\
$\begin{array}{l}\text { Frame } \\
\text { evident }\end{array}$ & $52(45)$ & $30(25)$ & $18(15.6)$ & $27(23)$ & $28(25)$ & $58.5(52)$ & $4(4)$ \\
$\begin{array}{l}\text { TV stories }(\mathrm{N}=39) \\
\text { Mean } \\
\text { references }\end{array}$ & 4.87 & 1.97 & 0.92 & 1.92 & 1.03 & 5.31 & 0.38 \\
$\begin{array}{l}\text { Frame } \\
\text { evident }\end{array}$ & 77 & 56.4 & 38.5 & 59 & 28 & 87 & 20 \\
\hline
\end{tabular}

Notes: The "mean references" number was calculated by dividing the sum of each subframe references and dividing it by the total number of stories. It is not on a scale, so the higher number means more references. The "frame evident" number represents the percentage of stories that had at least one reference to the subframe. For the press, the numbers represent the sample minus letters to the editor, with the full sample outcomes in parenthesis.

stake. This is contrasted with the line taken by the government's political opponents, whose aim it was to frame the government as confused and divided on the single currency decision. The Shadow Chancellor, Michael Howard's response to the announcement of the five tests typifies this strategy, which included seizing upon the supposed differences between Prime Minister and Chancellor:

There they sit. United in rivalry. Each determined to frustrate the other. Each determined to scheme against the other. Each determined to do the other down ... We all know they (the five tests) were written on the back of an envelope, in the back of a taxi, to fix the damage done by the Chancellor's spin doctor in the back of the Red Lion pub. It was a four-pint briefing, which led to a five-point plan, which has just given us a six-year run-around!

$\mathrm{H} 3$ is thus partially supported, as only some politicians were active sources in the strategic framing of politics, whereas others emphasised the substantive issues.

Having established the presence of the strategy frame as a whole in the news, attention will now turn to the elements of it that were most prominent (RQ1). Table 3 uncovers a number of interesting themes that characterised coverage of the euro debate. Letters to the editor are removed from the sample because their typical length was considerably 
shorter than other articles, often only a couple of sentences. Perhaps the most striking is the extraordinary preoccupation in the press and TV with the relationship between Tony Blair and Gordon Brown. Around half of all press articles and three quarters of TV news stories had at least one reference to the "struggle for power" between the two men at the top of government. This proportion rises to $70 \%$ of "main news" stories in the press (the front three pages), illustrating how this subframe dominated the news agenda.

A significant proportion of press and TV coverage of the single currency was also focused on the manoeuvrings within and between the political parties. Policy differences are of course inevitable and desirable, but these reports interpreted the strategic motivations behind positions adopted, often using the language of war, such as in this extract from a Financial Times article: "Mr Blair parried the attack by seeking to highlight perceptions that Mr Duncan Smith has an extremist position on the euro" (Blitz and Crooks, 2003). "Presentation style" was the most consistently used subframe, appearing in over half of all press articles and $87 \%$ of TV news reports. This is perhaps more than we would expect in a non-election context, and demonstrates that commentary on political spin and the aesthetics of political statements are deeply embedded in contemporary UK political journalism. Although not an election campaign, around a quarter of all press and TV reports on the euro debate still contained references to the "horserace" of opinion polls.

\section{Discussion}

Carefully building upon previous research conducted in different contexts, this study aimed to understand the prevalence of strategic framing in the UK during a non-election policy debate. The strategy frame was found to be a commonly adopted framework by journalists, appearing in $86 \%$ of newspaper articles and $97 \%$ of TV news stories. Around $44 \%$ of newspaper and $59 \%$ of TV news stories were either "very" or "quite" strategy framed. Although the measurement of the strategy frame used in this study is slightly different to others in this field, the results are comparable. For example, in their study of the health care reform debates of 1993-4, Cappella and Jamieson (1997) found $67 \%$ of news items primarily in terms of political strategy and $25 \%$ issue. In her content analysis of welfare reform in 1996, again in the USA, Lawrence (2000) found $41 \%$ of stories primarily game framed. Strategy, then, was clearly a prevalent narrative presented to news media during the euro debate. But there are a number of further findings that should confirm as well as qualify many media critics' worries about current political journalism. They are as follows: Strategy frames work in 


\section{Dan Jackson}

conjunction with issue-based topics. Very few stories did not have an element of both frames. This should temper some fears that strategy reporting is displacing issues completely. For journalists, the overlap of frames probably reflects their professional desire to give a complete account of events or issues: by outlining some of the issues at stake, but then also giving an account of the political motivations behind the debate, and strategies for success (Esser and D'Angelo, 2006). In the case of the euro debate, they did this to differing degrees. Often, the EMU story got into the news because of the latest development in the saga of the political game (such as developments in the supposed divisions within the government), and then context to the decision was given later in the article, providing the issue frame. TV news was far more strategyoriented than newspapers ( $R Q 2$ ). Like newspapers, all broadcasters covered the strategic element of party posturing and tactics during the euro debate. However, whereas in the newspapers these strategy stories were to an extent balanced out by some serious analysis of the issue deeper in the paper, this was rarely present in $\mathrm{TV}$, whose reporting was more episodic and events-led. In short, there is little evidence that TV news would engender an understanding of the single currency issue in its viewers; rather, it was more likely to deepen understanding of the strategic reasons that politicians supported or opposed EMU.

There are two reasons why TV news coverage has extra significance for shaping attitudes. The first is reach: $65 \%$ of Britons consider TV as their main source of political information compared to $15 \%$ for newspapers (Hargreaves and Thomas, 2002), and a combined audience of 10 million viewers watched the main TV news every night in 2003. The second reason is trust: $70 \%$ of the public trust television journalists to tell the truth compared to $10 \%$ for tabloid journalists (ibid.). So the fact that viewers of TV news received a fragmented and strategy-laden account of the euro debate is even more worrying in this respect.

As Kerbel et al. (2000) explain, the strategy frame may be particularly appealing for TV journalists during an election campaign because it can be partly driven by an adherence to a norm of objectivity, or "principled detachment", which is less of an imperative for the press. For TV journalists, objectivity is a thorny matter, and reporters must make decisions about what subjects and perspectives constitute dispassionate coverage. Having mutually accepted standards for what comprises appropriate election news reduces the risk of appearing biased, and therefore covering elections from the strategic perspective serves this end (ibid.). The euro debate arguably creates similar conditions for journalists, because of its divisive history and because it will ultimately be decided in a referendum. Just like with elections, therefore, journalists tried to maintain a healthy distance from both the pro and anti-euro sides by highlighting 
their daily conflicts in Westminster, addressing how they were performing in the horse race of opinion polls, and discussing the strategies employed to outmanoeuvre opponents.

In this sense, the focus on strategy is probably as well explained by broadcast journalist professional norms as much as an in-built cynical perspective of political affairs. But this is still not without its problems, because if the aim is to increase public understanding of a complicated issue, then simply offering an update in the political game can be counterproductive, because complex debates are simplified into polarised positions, potentially creating more heat than light for the public (Bond, 2005). Furthermore, this study found that the way these rows end up being framed by the media is often not as principled stands, but as cynical manoeuvres in order to appeal to a voter segment or outflank opponents.

Although individual differences between newspapers and TV channels existed, there were no real differences between newspaper sectors or publicl commercial TV channels in terms of the prominence of strategy reporting. Consequently, $\mathrm{H} 1$ was supported and $\mathrm{H} 2$ was rejected. As few studies of this kind have been conducted in the UK, there is little comparable research looking at the strategy frame between different types of broadcasters and newspapers, though TV findings were consistent with Kerbel's (2000) study of US election news, and previous UK election content analyses (e. g. Deacon et al., 2005; Norris et al., 1999). Given the similar PSB traditions and regulations that each of the UK terrestrial news broadcasters operate within, it was expected that commercial and publicly funded channels would present the issue largely the same. But on the other hand, without the pressure typically felt by commercial channels, the BBC should arguably be able to frame the issue in any manner it chooses. This coverage might include a larger proportion of stories explaining the issues behind the debate, policy positions and consequences of EMU. However, in this case, their audiences largely experienced the debate the same way as those of their commercial counterparts.

Due to their greater amount of space given to informative analysis and comment and their less commercially oriented agenda, $\mathrm{H} 2$ expected quality newspapers to focus more on the issues than strategies surrounding the euro debate, but this hypothesis was not supported and is actually consistent with recent UK election content analyses (see Deacon et al., 2005). The qualities did have more actual analysis of the issues underpinning EMU than other newspapers, but they also had more analysis of strategy as well. Interestingly, there was more of a relationship between a paper's partisan position on the single currency than their 
sector in their framing of the debate. It is worth noting that anti-euro newspapers, which tended to focus more on strategy, attract a far greater readership than pro-euro titles.

Politicians are not necessarily the innocent victims of a strategy-obsessed media (H3). This is an important finding, and underlies the need for the contribution of politicians in news stories to be a consideration in the debate about strategy framing. Findings corroborate those of Gaber (2005), but an interesting theme to emerge was that the agendas of the government and opposition in the euro debate could not be more different: whereas the government wanted to present the euro decision as a rational assessment of its economic benefits, the opposition's contribution to the debate was to frame it as a power struggle between cabinet factions. The lines adopted by the major parties were carefully scripted to suit their strategic agendas. For the Conservatives, there was a deliberate strategy to focus on government divisions rather than the issues, as they obviously thought there was more political capital to be gained. But this might not be the case with different policy debates during which opposition parties may feel they can cause more damage to the government by focusing on issues. Further research can shed light on this.

At the culmination of the policy debate, strategy news was not substantially more prominent than earlier (H4). This finding somewhat contrasts with previous American literature (Lawrence, 2000). Findings showed that in short, when the policy decision was being debated and decided both behind closed doors and in the public sphere, the news more commonly offered strategic angles. Once the decision had been announced, the news placed greater emphasis on the issues; hence results only partially support $\mathrm{H} 4$.

If we accept Cook's assertion that "daily news stories are episodes of larger continuing sagas" (1996, p. 474) then a saga that applied to this case study was that of Britain and the single currency, underpinned by the broader saga of Britain's ongoing relations with the EU. In order for news to be produced routinely, Cook argues that journalists need to visualise events as part of a larger storyline and must move the plot along from one episode to the next. This applies well to the development of the euro debate, and helps us understand the newsroom decisions that resulted in the coverage found in this study. The substantive issues surrounding the single currency are considerable: for instance, the impact of joining (or not) on jobs, prices, trade, business, finance and sovereignty. But these issues did not always translate into newsworthy events that might move the passage of the EMU saga from one phase to the next (see Gavin, 2000). There were exceptions, such as when a group of influential businessmen wrote a jointly signed letter in favour 
of euro entry based on its economic benefits (May $12^{\text {th }}$ ), or when the head of General Motors announced that euro entry was not vital for his company in terms of investing in a country (May $13^{\text {th }}$ ). Both of these news events were newsworthy because they contributed to the saga of the single currency decision and enabled journalists to focus on important issues that may educate their audience. But they were few and far between, unlike strategy-related events. Cook (1996) sees policy-making as most newsworthy when it is marked by clear conflict that promises resolution: "conflict with movement". The euro debate offered plenty of this, and a situation of controlled conflict lent itself well to strategy framed news because it provided clear chronological markers of journalists' idealised phase structure. As a result, throughout most of the sample period, when the EMU story was most visible in the news it was usually as a result of a strategy-related event or development.

It is arguably very reasonable for journalists to focus more on Westminster affairs when policy is being debated, and that when it has been decided, attention might then turn to its implementation and possible consequences beyond Westminster. But if this is a phase structure typically applied to other policy debates, it could crowd out or delay substantive coverage of those issues, as in the case of the 2003 euro debate. Furthermore, it is perhaps rather worrying that news organisations were most likely to approach the political world with the superficial and cynical strategy schema at precisely the time when public opinion was most likely to be formulated, mobilised, and listened to by politicians. Because this is a case study, the typicality of this phase structure to other UK policy debates cannot be assumed, and so should be an imperative for future research.

Prominent subframes (RQ1) were both specific to the policy debate (the Brown/Blair saga) and generic (presentation style). The Brown/Blair story accounted for more media attention than inter-party politics, which traditionally provide the material for strategy frames during elections. The prominent use of the Brown/ Blair subframe is interesting because although it appeared in this case study, it was a pre-existing frame that was applied by journalists in order to interpret the euro debate. Media speculation about their relationship had been a common frame since the mid-1990s and continued well beyond 2003, so it is likely that many other policy debates saw heavy use of this frame. From a journalistic perspective, it is perhaps understandable why the frame was appealing during the euro debate, as it represented an ongoing saga in which the negotiations over the single currency provided new twists; in this sense it made the EMU subject more newsworthy as it could be presented in familiar terms. 


\section{Conclusion}

The implications of this study's findings can be considered in terms of both the quality of information the British public receives on Europe, and (more tentatively) the normative role of news journalism in promoting political engagement. With these in mind, there was arguably no shortage of substantive, issue-based coverage (at least in the press), but it was invariably tainted by the presence of strategic frames, with their undertones of cynicism and manipulation. A number of empirical studies have found that the presence of strategic frames in otherwise issue-based news is enough to induce cynical views of the political process, and erode feelings of political efficacy (e.g. Cappella and Jamieson, 1997; de Vreese, 2004). For this reason, the heavy doses of strategic frames during the euro debate should not be taken lightly, as they can be taken as further evidence that under certain circumstances the news media may be impeding aspects of civic engagement.

Examining coverage over time showed that issue-based news found itself relegated to the periphery of the news agenda until the few days around the policy announcement. Combined with the paucity of issuebased coverage in television news, it is hard to see how avid broadsheet readers aside, most British citizens would be able to build an informed opinion on the single currency, and it is easier to see why they feel confused about and ignorant of EU affairs. Results also suggested that despite their complaints about strategic news, politicians should take their share of blame for the quality of news the British public receive on the EU, as they were responsible for keeping the focus on strategies over issues at times. The findings therefore provide a qualification to some of the orthodox understanding behind strategy news, which sees it as a preoccupation of the media only (see Patterson, 1997). One could explain this finding by the nature of the issue, the EU, which has traditionally caused both inter and intra-party division, and so provides an easy basis for stories to be based around conflict. But there are regularly policy debates in and outside the UK where the parties disagree, thus suggesting that trends in coverage found here may appear elsewhere. National context may also explain the role of politicians in strategy news, whereby Britain's adversarial political system (Cole, 2002) encourages the media to seek oppositional remarks from political opponents in order to provide balance to a story (see de Vreese, 2005a). But this system is not unique to Britain, and is not far removed from the two-party system in the USA. It is also unlikely given the predilection of journalists for conflict reporting in more consensual political systems of northern Europe (de Vreese, 2005a, Peter et al., 2003). It is therefore most likely that the contribution of politicians towards the strategy frame has been 
an overlooked aspect of the theory, and so deserves closer monitoring in further research.

But it is also important not to exaggerate this finding. It is true that politicians did add to the flow of strategy stories during euro debate, but on the other hand there were times when they genuinely tried to make constructive contributions. However, the news media - often supported by political opponents it must be said - were all-too-willing to pounce upon such pronouncements as evidence of division or self-interested manoeuvring. The end result was the creation of an environment whereby it was very difficult for politicians of any side to make meaningful contributions to the euro debate. The likelihood is that this scenario applies to policy debates beyond that of the single currency, as it is consistent with observations of a "vicious circle" evolving at the heart of contemporary political communication, whereby mutual distrust between the media and politicians leads to a decline in the quality of political information for the public (Lilleker et al., 2002; Stanyer, 2007), Brants et al. (2010) recently referred to this dysfunctional relationship as "the real spiral of cynicism" in contemporary politics.

By examining the political strategy subframe at various levels, there is scope to understand exactly who is being strategically framed. This will differ depending on the context of the study, but it would be interesting to observe the role of opposition parties during policy debates, or opposing candidates/parties during elections, and whether they pursue a deliberate strategy of framing opponents as cynically motivated schemers. From what we know of strategic framing effects and its effects on political cynicism, there may be significant advantage to be gained by framing political rivals strategically whilst avoiding this sort of coverage yourself. Indeed, it is possible that media bias towards parties, candidates or policies may influence the number of strategic frames attributed to certain politicians. Again, this matters because of the possibility that the public becomes cynical about some politicians and not others, based on the amount of strategic coverage. Many studies examining the news media's role in elections determine which candidates or parties receive positive and negative coverage (e. g. Deacon et al., 2001; 2005), but future scholarship might also address who was strategically framed, and by whom.

Given some of the unique characteristics surrounding Britain and the EU, we should be cautious about drawing universal conclusions about strategic framing and inter-election policy debates. With this in mind, the findings of this study offer some intriguing and important questions for further research. For example, a content and/or effects study that analysed a number of policy issues that differed in terms of the level of elite conflict, the politicians at the forefront of the debate, the level of public knowledge of the issue, the direction and stability of public opin- 
ion, and electoral time-scale of the issue (i.e. whether there was a clear finishing line for legislation, or whether it was conducted near the start or end of an electoral cycle), would deepen our understanding of under what circumstances strategy narratives enter the news and how contextual variables moderate their effects on audiences.

\section{Bionote}

Dan Jackson is Senior Lecturer at The Media School, Bournemouth University, UK.

\section{Notes}

1. In order to qualify for analysis, articles and TV news stories must mention a keyword in two independent sentences. Keywords used were "euro", "single currency", "EMU", "European Monetary Union", "five tests" and "5 tests". This is consistent with similar studies where the focus is on coverage of EU issues (e. g. de Vreese, 2005a), and ensures that the most relevant stories were selected.

2. For example, de Vreese (2005a) measured the economic consequences frame through three measures: "Is there a mention of the costs/degree of expense involved?", Is there a reference to economic consequences of pursuing or not pursuing the action?", and "Is there a mention of financial losses or gains now or in the future?". All were answered with a Yes (1) or No (0) to make the overall frame score out of 3 , which was then recoded into a $0-1$ scale.

3. The formula used for calculating the overall frame is as follows: Every sentence in a story that includes a strategy or issue subframe is coded as one reference. If there are three times more strategy than issue references in a news story (e. g. 15 strategy and 4 issue), then the overall frame is classified as "very strategy" (and vice versa if there are three times more issue references). If there are $50 \%$ more strategy than issue references in a news story (e.g. 15 strategy and 9 issue), then the overall frame is "quite strategy" (and vice versa if there are $50 \%$ more issue references). If there is less than $50 \%$ more references to subframe than the other (e.g. 15 strategy and 11 issue) then the overall frame is "mixed".

4. Despite it being part of Cappella and Jamieson's (1997) conceptualisation of strategic news, a distinct subframe for the language of war, games and competition was not included. This is not to say that journalists did not use such language, but rather that it was invariably applied in the context of the other subframes, such as the Brown/Blair relationship and inter-party politics (as part of the political strategy frame). Therefore, in order to retain the distinctiveness of the coding categories, sports and war metaphors were not explicitly coded.

5. The intercoder agreements on each of the strategic subframes were as follows: Brown/Blair relationship, press $\mathrm{k}=.90$, TV news $\mathrm{k} .94$; intra-cabinet politics, press $\mathrm{k}=.76$, TV news $\mathrm{k} .79$; intra-party politics, press $\mathrm{k}=.86$, $\mathrm{TV}$ news $\mathrm{k}=.88$; interparty/camp/lobby politics, press $\mathrm{k}=.89, \mathrm{TV}$ news $=.86$; horse race subframe, press $\mathrm{k}=.94, \mathrm{TV}$ news $\mathrm{k}=.97$; presentation style subframe, press $\mathrm{k}=.82, \mathrm{TV}$ news $\mathrm{k}=.75$; overall meta frame (e. g. very strategy), press $\mathrm{k}=.85$, $\mathrm{TV}$ news $=.82$.

6. 6 Political editors spoke for an average of 2.10 minutes per story to the government politicians' 1.03 minutes. 


\section{References}

Barnett, S., Seymour, E., \& Gaber, I. (2000). From Callaghan to Kosovo: Changing Trends in British Television News 1975-1999. London: ITC.

Blitz, J., \& Crooks, E. (2003). Brown and Blair Call For Engagement with Europe. The Financial Times, $12^{\text {th }}$ June, p. 4.

Bond, M. (2005). Insular by Default? How the BBC Presents Europe to the British Public. European Movement Policy Paper 3, http://www.euromove.org.uk, accessed 6 December 2007.

Brants, K., de Vreese, C. H., Moller, J., \& van Praag, M. (2010). The Real Spiral of Cynicism? Symbiosis and Mistrust between Politicians and Journalists. The Harvard International Journal of Press/Politics, 15(1), 25-40.

Cappella, J. N., \& Jamieson, K. H. (1997). Spiral of Cynicism: The Press and the Public Good. New York: Oxford University Press.

Cole, M. (2002). Adversary Politics and Proportional Representation. Political Quarterly, 70(2), 166-174.

Cook, T. E. (1989). Making Laws and Making News. Washington, DC: Brookings.

Cook, T. E. (1996). Afterword: Political Values and Production Values. Political Communication, 13, 469-481.

D’Angelo, P. \& Kuipers, J. A. (Eds.) (2009). Doing News Framing Analysis. London: Routledge.

Deacon, D., Wring, D., Billig, M., Downey, J., Golding, P., and Davidson, S. (2005). Reporting the 2005 UK General Election. London: Electoral Commission.

de Vreese, C. H., Peter, J., and Semetko, H. A. (2001). Framing Politics at the Launch of the Euro: A Cross-national Comparative Study of Frames in the News. Political Communication, 18, 107-122.

de Vreese, C. H. (2004). The Effects of Strategic News on Political Cynicism, Issue Evaluation, and Policy Support: a Two-wave Experiment. Mass Communication and Society, 7(2), 191-214.

de Vreese, C. H. (2005a). Framing Europe: Television News and European Integration. Amsterdam: Her Spinus.

de Vreese, C. H. (2005b). The Spiral of Cynicism Reconsidered. European Journal of Communication, 20(3), 283-301.

de Vreese, C. H., Banducci, S. A., Semetko, H. A., \& Boomgaarden, H. G. (2006). The News Coverage of the 2004 European Parliamentary Election Campaign in 25 Countries. European Union Politics, 7(4), 477-504.

de Vreese, C. H., \& Elenbaas, M. (2008). Media in the Game of Politics: Effects of Strategic Metacoverage on Political Cynicism. The Harvard International Journal of Press/Politics, 13(3), 285-309.

Druckman, J. N. (2005). Media Matter: How Newspapers and Television News Cover Campaigns and Influence Voters. Political Communication, 22(4), 463-481.

Entman, R. M. (2005). Foreword. In, K. Callaghan and F. Schnell (Eds.), Framing American Politics. Pittsburgh, PA: Pittsburgh University Press.

Esser, F., \& D'Angelo, P. (2003). Framing the Press and Publicity Process: A Content Analysis of Meta-coverage in Campaign 2000 Network News. American Behavioral Scientist, 46, 617.

Esser, F. \& D'Angelo, P. (2006). Framing the Press and Publicity Process in German, British, and U.S. General Elections: A Comparative Study of Metacoverage. The Harvard International Journal of Press/Politics, 11(3). 44-66.

Farnsworth, S. J., \& Lichter, S. R. (2007). The Nightly News Nightmare: Television's Coverage of U.S. Presidential Elections, 1988-2004. Lanham, MD: Rowman and Littlefield. 


\section{Dan Jackson}

Gaber, I. (2006). Dislocated and Distracted: Media, Parties and the Voters in the 2005 General Election Campaign. British Politics, 1, 344-366.

Gavin, N. T. (2000). Imagining Europe: Political Identity and British Television Coverage of the European Economy. British Journal of Politics and International Relations, 2(3), 352-373.

Gleissner, M., \& de Vreese, C. H. (2005). News About the EU Constitution. Journalism, 6(2), 221-242.

Hahn, K., Iyengar, S., \& Norpoth, H. (2002, August). Consumer Demand for Election News: The Horserace Sells. Paper presented at the Annual Meeting of the American Political Science Association, Boston, 30. August, 2002.

Hargreaves, I., and Thomas, J. (2002). New News, Old News, ITC/BSC Report. http:// www.itc.org.uk/itc_publications/audience_research/index.asp, accessed 5 November 2005 .

Iyengar, S. (1991). Is Anyone Responsible? How Television Frames Political Issues. Chicago: University of Chicago Press.

Jamieson, K. H. (1992). Dirty Politics. Oxford: Oxford University Press.

Just, M., Crigler, A., \& Buhr, T., (1999). Voice, Substance and Cynicism in Presidential Campaign Media. Political Communication, 16(1), 15-24.

Kerbel, M. R., Apee, S., \& Ross, M. H. (2000). PBS Ain't So Different: Public Broadcasting, Election Frames, and Democratic Empowerment. The Harvard International Journal of Press/Politics, 5(8), 8-32.

Kuhn, R. (2003). The Media and Politics. In P. Dunleavy, A. Gamble, R. Heffernan and G. Peele (Eds.), Developments in British Politics 7. Hampshire: Palgrave Macmillan.

Lawrence, R. (2000). Game Framing the Issues: Tracking the Strategy Frame in Public Policy News. Political Communication, 17, 93-114.

Lilleker, D. G., Negrine, R., \& Stanyer, J. (2002). A Vicious Circle: Politicians and Journalists in Britain's Media Democracy. Political Studies Review, Autumn 2002.

Morris, J., \& Clawson, R. A. (2005). Media Coverage of Congress in the 1990s: Scandals, Personalities, and the Prevalence of Policy and Process. Political Communication, 22(3), 297-313.

Norris, P., Curtice, J., Sanders, D., Scammell, M., \& Semetko, H. A. (1999). On Message: Communicating the Campaign. London: Sage.

Patterson, T. E. (1993). Out of Order. New York: Knopf.

Patterson, T. E. (1997). The News Media: An Effective Political Actor? Political Communication, 14(4), 445-455.

Patterson, T. E. (2000). The United States: News in a Free-market Society. In R. Gunther \& A. Mughan (Eds.), Democracy and the Media. A Comparative Perspective. New York: Cambridge University Press.

Peter, J., Semetko, H. A., \& de Vreese, C. H. (2003). EU Politics on Television News: A Cross-Comparative Study. European Union Politics, 4(3), 305-328.

Pfetsch, B. (2004). The Voice of the Media in European Public Sphere: Comparative Analysis of Newspaper Editorials, http://europub.wz-berlin.de/Data/reports/WP3/ D3-4 \%20WP3 \%20Integrated\%20Report.pdf, accessed 3 February 2008.

Project for Excellence in Journalism, (2004). The Debate Effect: How the Press Covered the Pivotal Period of the 2004 Presidential Campaign, http://www. journalism.org/node/163, accessed 23 June 2006.

Semetko, H. A., \& Valkenburg, P. M. (2000). Framing European Politics: A Content Analysis of Press and Television News. Journal of Communication, 50(2), 93-109.

Skorkjaer Binderkrantz, A., \& Green-Pedersen, C. (2009). Policy or Processes in Focus? The Harvard International Journal of Press/Politics, 14(2), 166-185.

Stanyer, J. (2007). Modern Political Communication. Cambridge: Polity Press. 
Strömbäck, J., \& Dimitrova, D. V. (2006). Political and Media Systems Matter: A Comparison of Election News Coverage in Sweden and the United States. The Harvard International Journal of Press/ Politics, 11(4), 131-147.

Strömbäck, J., \& Shehata, A. (2007). Structural Biases in British and Swedish Election News Coverage. Journalism Studies, 8(5), 798-812.

Strömbäck, J., \& van Aelst, P. (2010). Exploring Some Antecedents of the Media's Framing of Election News: A Comparison of Swedish and Belgian Election News. The Harvard International Journal of Press/Politics, 15(1), 41-59.

Valentino, N. A., Beckmann, M. N., \& Buhr, T. A. (2001). A Spiral of Cynicism for Some: The Contingent Effects of Campaign News Frames on Participation and Confidence in Government. Political Communication, 18, 347-367. 
